Other insects of interest in this association are the Belostomatidæ, of which several species occur. Their prey consists of mosquito, dragonfly and tabanid larvæ, which they seize with their prehensile forelegs.

In conclusion, attention may once more be directed to the rapidity with which the temporary swamps are colonized, and the intense and incessant competition among the colonists and its effect on the mosquito population. The comparative paucity of mosquitoes during the thick of the rains is a common experience in British Guiana, and is generally attributed to the destruction of larvæ by excessive flooding. While there may be something in this, there is little doubt that it is due in a far greater measure to the mosquito's aquatic associates. These are slower at colonizing at the onset of the rains, and cannot establish themselves at all in the ephemeral puddles that result from the intermittent showers towards the end of the season. This suggests a reason for the prevalence of mosquitoes at the beginning and at the end of the rains, and their scarcity when the rainy season is in full swing.

\title{
Obituary
}

\section{Dr. W. J. S. Lockyer}

$\mathrm{T}$ HE sudden death of Dr. Lockyer has deprived astronomical circles of a familiar and welcome figure. While walking down to his house from the Norman Lockyer Observatory on July 15 he was seen to fall on his face; and when some men close by went to help him up, he was found to be dead. About two years ago he was laid up for several months on account of phlebitis, and his death seems to have been a sequel to this attack.

To all his friends, Dr. William James Stewart Lockyer was affectionately known as 'Jim', and by all of them he will be greatly missed. He was the fifth son of Sir Norman Lockyer and was born on January 3, 1868. His mother died when he was eleven years of age, and the present Lady Lockyer was married to Sir Norman in 1903. The stages of Dr. Lockyer's education at Cheltenham College, Trinity College, Cambridge, the Royal College of Science, South Kensington, and the University of Göttingen, all led naturally to a scientific career and to his carrying on the astronomical studies of his distinguished father. The subject of the thesis for which he received his doctorate at Göttingen in $\mathbf{1 8 9 6}$ was the variable star $\eta$ Aquilæ, all the available observations of which he submitted to full discussion with some interesting conclusions. Among the results obtained was that the epoch of maximum luminosity oscillates to and fro to the extent of five hours on either side, with a period comprising four hundred maxima. The minima are also subject to a similar oscillation, and four secondary undulations were revealed on the curves representing the variability of the star's magnitude, recurring at intervals of forty-three hours, or one-quarter of the main period.

Variability of another kind, namely, that of the spectrum of the star $\gamma$ Cassiopeiiæ, was the subject of Dr. Lockyer's most recent papers to the Royal Astronomical Society. This star has a constant magnitude of $2 \cdot 25$, and its spectrum was also believed to be constant until a close examination of photographs taken by Dr. Lockyer proved it to change in a very peculiar manner. The spectrum contains hydro. gen lines each made up of double emission lines superimposed on a broad absorption line. The two components of each of the double emission lines undergo regular changes of relative intensity; and in his last paper on this star, contributed to the Royal Astronomical Society a little more than a year ago, evidence was presented of some very remarkable variations of this character.

This paper was one of forty dealing with spectroscopic work carried out at the Norman Lockyer Observatory, Sidmouth, since 1920, nearly all of them by Dr. Lockyer himself. The Observatory was founded by Sir Norman with the help of sympathetic friends in 1912, after the decision to transfer to Cambridge the Solar Physics Observatory in which he had carried on astrophysical and astrochemical work continuously since 1875 . It was first called the Hill Observatory, but was given its present name after Sir Norman's death in 1920. Four years earlier, the Norman Lockyer Observatory had been formed into a Corporation under the Companies (Consolidation) Act, 1908, with Sir Robert Mond, who was a school friend of Dr. Lockyer's at Cheltenham College, as chairman. Dr. Lockyer succeeded his father as director of the Observatory in 1920, and though he usually had only one assistant observer, the amount of original work done has been remarkable, with the result that the Observatory now possesses as fine a collection of photographs of stellar spectra as any observatory in Great Britain. Such a record is particularly good for an institution maintained entirely by private benefactors and without any State aid.

Both in association with his father, and separately, Dr. Lockyer took part in a number of total solar eclipse expeditions. Among these were Government expeditions to observe the Vadso (Lapland) eclipse of 1896; Viziadrug (India), 1898; Alicante (Spain), 1900 ; Palma (Majorca), 1905 ; and Vavau (Tonga Islands), 1911, when he was the chief of the expedition. Other eclipses observed by him were those of 1912 (France); 1921 (Scotland); 1927 (England); 
and 1932 (Canada), and whenever weather conditions were favourable he was successful in adding something to our knowledge of solar phenomena revealed during totality. His skill as a photographer, and familiarity with astronomical instruments, made him particularly valuable to every eclipse expedition of which he was a member.

While certain problems relating to the constitution of the sun can only be studied during the brief moments of total eclipse, there are many others which require for their solution the collection of observations over a long period. Among these is the relation between solar changes and terrestrial weather, to which subject Sir Norman and his son contributed some notable papers. Upon the initiative of Sir Norman, a committee for the study of such changes was appointed by the International Meteorological Committee in 1903, and Dr. Lockyer became secretary of it. Periodic plus and minus 'pulses' of rainfall in India were described by Sir Norman and Dr. Lockyer in a paper read before the Royal Society in November 1900, and were shown to be related (sometimes inversely) to similar variations at Mauritius, Cordoba (South America), the Cape of Good Hope, and other places. Attention was afterwards devoted to an examination of the variations of pressure over the Indian and other areas, and a period of 3.8 years was found in the mean variation over the whole of India and the other areas. An inverse variation was found in the pressures at Cordoba ; in fact, there was a 'see-saw'. The area affected by this barometric seesaw was extended in a later paper before the Royal Society to Java, Ceylon, Mauritius and Australia.

These studies of periodic variations in the earth's meteorological elements are closely related to solar conditions. It was shown by Dr. Lockyer that, underlying the ordinary solar cycle of eleven years, there is another of greater length, namely, thirtyfive years, or about three cycles of solar activity. This corresponds to Brückner's well-known climatic cycle of about thirty-five years, and thus associates weather changes on the earth with periodic variations of solar phenomena. What exactly is the relationship between the two sets of changes has yet to be determined, and the criterion of correlation coefficients has taken the place of that of curve parallels, but Dr. Lockyer's studies of the problem are still important contributions towards its solution.

Dr. Lockyer was keenly interested in aeronautics, and he made his first ascent in a balloon in 1907, with the late Hon. C. S. Rolls as pilot. For the next few years he was in the air in balloons and aeroplanes as often as his work or chance permitted, invariably accompanied by his camera and frequently with other scientific instruments, such as experimental direction finders and similar gadgets. During the Great War he was commissioned in July 1915 as a lieutenant in the Royal Naval Volunteer Reserve, attached to the Royal Naval Air Service, and two years later was promoted to the rank of lieutenantcommander. $\mathrm{He}$ served as commanding officer at several anti-Zeppelin stations and also in other capacities, such as intelligence officer to H.Q. Manston and Westgate R.N.A.S., ground instructor Nether- avon (Wilts), and meteorological officer at Burnham Newton (Norfolk) and Orfordness (Suffolk). He became full major in the Royal Air Force in 1918 and was demobilized in August 1919, when he again took up his astronomical work.

Dr. Lockyer served on the Council of the Royal Astronomical Society from 1927 until 1929, and again from 1931 until the present year; he was also a vicepresident of the Society in the period 1933-35. $\mathrm{He}$ was honorary lecturer in astronomy at University College, Exeter, but most of his active life was devoted to observational work at South Kensington and later in the Observatory founded by his father on the top of Salcombe Hill, overlooking Sidmouth. He was married, and his widow survives him, but he leaves no children to continue or extend the work which has given the name of Lockyer a permanent place in the history of astronomical science. He will, however, not only be remembered in these records, but also by a large circle of personal friends, who will long cherish his memory with affection and esteem.

\section{Baron Axel von Klinckowström}

The death of Baron Axel von Klinckowström, which occurred in the month of May at his home, the family estate of Stafsund on the island of Ekerö near Stockholm, removes one of the few remaining links with Nordenskiöld, the explorer. Klinckowström, who was born in 1867, accompanied Nordenskiöld to Spitsbergen in 1890 as a young zoologist, and in 1891 himself undertook a zoological expedition to Surinam. After his return, he devoted himself to biological research first at Stockholm and later at Würzburg under Sachs and Boveri. During these years he published a number of contributions to embryology, anatomy, variation and inheritance.

In 1895 Klinckowström was appointed University lecturer at Stockholm, and later undertook a number of expeditions to the Arctic and Antarctic. On his return he enriched the museums of Sweden by the presentation of his valuable collections. In his later years he devoted himself to bacteriological research carried out in his private laboratory at Stafsund. His many-sided interests embraced poetry and the history of art, and he was well known in Sweden as a writer of books of travel and adventure. His many friends will cherish the memory of a charming personality.

E. KLIENEBERGER.

\section{WE regret to announce the following deaths :}

Dr. Charles E. Johnson, director of the Roosevelt Wild Life Station at the New York State College of Forestry, on June 6, aged fifty-six years.

Prof. A. P. Karpinsky, president of the Academy of Sciences of the U.S.S.R., well known for his work in geology and palæontology, on July 14, aged eighty. nine years.

Prof. J. H. Müller, professor of chemistry of the University of Pennsylvania, an authority on the chemistry of germanium, on June 18, aged fifty-three years. 